\title{
EDITORIAL
}

Niarie, ao pesquisar os Mali eentrar em contato com os generalistase memorialistas dessa cultura teve a oportunidade de ouvir de um deles o seguinte:

"Ensino aosmeus a história de seus ancestrais, de modo que as vidas dos antigos possam servir de exemplo, pois o mundo é antigo, mas o futuro brota do passado"

Foi pensando no sentido dessas palavras que me dispus a ir em busca dos primeiros tempos da Faculdade de Filosofia, Ciências e Letras de Ribeirão Preto, na tentativa de recuperar fatos, pessoas, mas sobretudo o Trabalho que ela desenvolveu de março de 1964 até hoje, particularizando, sem dúvida, para a área da Psicologia e da Educação.

E fazer isto foi muito prazeroso...

Mas, exatamente por ter participado da vida na Filosofia ao longo de todo esse tempo, esse não é um relato isento. Ele traz, lá do passado, uma compreensão mais apurada da evolução acontecida, do Valor que deve ser atribuído a essa Faculdade, que nasceu Instituto Isolado e só onze anos depois passou a fazer parte da Universidade de São Paulo; entretanto, ele carrega também, a visão emocionada de quem " navegou em muitas lembranças, amarrou pedaços de imagens" para compor o "de onde viemos e por onde andamos nesses 30 anos".

\section{FACULDADE DE FILOSOFIA, CIÊNCIAS E LETRAS DE RIBEIRÃO PRETO}

Faculdade de Filosofia, mas ela nasceu, sem dúvida, como uma Faculdade de Ciências. Desdeo Vestibular se estava diante de "algo diferente, estranho, novo ". Dirse-ia que a idealização com que A FFCL se implantava, fazia com que o "Espírito" que a dominava fosse uno, único, mas amplo, muito amplo... de tal forma que ele permitia abrigar o lado da Formação Científica, aliado ao do Ensino, terminando no Profissional. Havia um primeiro ano propedêutico, e desde o início foi dado aos alunos a oportunidade de trabalhar... e não com teorias! A Ciência era a opção: a Experimentação, a Observação, as estratégias para fazerem os dados aparecerem.

O ensino estava voltado para a ação e as aulas centravam-se nas atividades práticas. Dr Lucien Lison, Diretor e Fundador da FFCL, junto, em especial com os professores Heni Sauaia, Thereza Pontual de Lemos Mettel, José Vasconcelos e Sebastião Barbosa foram, aos poucos, introduzindo os alunos nos "mistérios " das novas perspectivas do que pretendiam fosse uma formaçăo universitária adequada . 
Nos primeiros anos da FFCL, os estudantes que aqui chegavam eram despertados para um "querer trabalhar e participar da construção de uma Escola, de um espaço para a Ciêncią". Não havia dificuldades que não se buscasse contornar; a improvisaçăo marcava todos os passos; e se observava uma proximidade amena no contato entre as geraçðes que partilhavam um imenso entusiasmo, fazendo desaparecer qualquer perspectiva menos otimista quanto aos frutos de uma tal Educação. Conseguia-se juntar forças e trabalhar nas mesmas metas.

Incentivo constante d inventividade... Nada vinha pronto e tudo precisava ser pensado e construido. Não existiram nem muitas e aprofundadas leituras ( em especial as teóricas ), mesmo porque não eram muitos os livros, e, as revistas só foram chegando aos poucos. Com isso, foi possível aprender a construir e os alunos se acostumaram com o começo pelo primeiro passo, desenvolvendo um raciocínio prático e crítico. Empirismo!

Hoje, quando olho para trás, consigo distinguir que havia "qualquer coisa" de muito especial que guiava a FFCL no escuro da época que se vivia e da confusão em que estavam os Institutos Isolados.

30 anos ...

O que aconteceu a essa Faculdade ao longo desse tempo?

Será que ela vem cumprindo os objetivos a que se propunha?

Quem é, hoje, a Faculdade de Filosofia, Ciências e Letras de Ribeirão Preto enquanto uma das Unidades de um Campus do interior da Universidade de São Paulo?

Resposta primeira: De 1967 a 1993 a FFCLRP formou 2187 profissionais, sendo 135 em Licenciatura em Ciências, 827 em Biologia, 392 em Química e 833 em Psicologia.

Dentro desse ângulo, o da Formação de Alunos - sua profissionalização contribuição prioritária de uma Universidade para a Comunidade, dois fatos permitem que se veja o acerto do trabalho aqui desenvolvido: primeiro, o índice comparativamente muito elevado de Bolsistas de Iniciação Científica, nas diferentes Graduaçð̃es, o que tem como consequência, um número grande de egressos da FFCLRP-USP que são aprovados nos Programas de Pós-Graduação mais exigentes e estão contratados nas Universidades Públicas do País; por outro lado, nossos ex-alunos, vêm sendo sistematicamente selecionados para as Residências e Aprimoramentos nos Hospitais, nas diversas áreas de atuação do Psicólogo; os licenciados, em Biologia e Química, principalmente, lecionam nas escolas mais gabaritadas da cidade e da região, tendo se efetivado depois de concursos concorridos. Tudo isto leva a crer que os caminhos por onde se tem andado permitem "bons frutos".

Como corolário, de $1980 \mathrm{em}$ diante, paulatinamente foram sendo aprovados e instalados cursos de Pós-Graduação, vinculados aos 4 Departamentos que compoem a FFCLRP hoje: Departamento de Biologia, Departamento de Geologia, Física e 
Matemática, Departamento de Psicologia e Educação, Departamento de Química. Esses programas tém sido avaliados com conceito A e já formaram 175 mestres e 6 doutores. Com esses Programas cresceu o contato com outras Unidades da USP, com Laboratórios da UNICAMP e dos diversos Campi da UNESP, muitas vezes formando Grupos de Pesquisa e desenvolvendo Projetos Integrados.

Resposta segunda: De acordo com o anuário Estatístico da USP, a Produção cientifica dos docentes da FFCLRP-USP faz dela "das dez mais"; isto por si só já deveria colocá-la em um pedestal, até porque temos exatamente a metade da idade de outras tantas Unidades, que quando nascemos tinham ultrapassado a maioridade e se tornado "balzaqueanas ". Viemos, de fato, com muito fôlego! E o reconhecimento se faz sentir até no montante de verbas que as agências financiadoras - FAPESP, CNPq, CAPES, FINEP - costumam destinar aos projetos de docentes da FFCLRP - USP .

Resposta terceira: Mas, a FFCLRP não é só Pesquisa e Ensino; ela comporta ainda todo um trabalho de Extensão de Serviços à Comunidade. Sð̃o Conferências, Cursos em Escolas, Atendimento Psicológico - a crianças, adolescentes, adultos Assessorias e Consultorias a Órgãos Públicos... numa inserção verdadeira e constante.

\section{Pensando as Linhas de Evolução da FFCLRP}

Sem dúvida, nascemos com o respeito pelo Conhecimento Científico e o mantivemos firme nesses 30 anos. Somos 120 docentes, dos quais 111 em RDIDP. Mas, aprendemos certa humildade: necessitamos das outras áreas do conhecimento, não podemos ficar ilhados. A Psicologia, a Biologia, a Química, a Física, a Matemática, a Educação - para falar apenas das primeiras áreas departamentais previstas em 1964 se colocam como essencialmente parte de um conjunto que aceita, incorpora e prega a Interdisciplinaridade.

Da mesma forma, partimos e caminhamos muito tempo numa Abordagem essencialmente empírica, entretanto fomos aprendendo a buscar e a trabalhar as teorias e fundamentalmente a respeitar o conhecimento que vem do passado, a pesquisar a literatura ...

Pensando essa evolução, não há como não ter a expectativa de que os próximos 30 anos sejam a continução, em ritmo mais acelerado, da realização de um trabalho sério e de valor.

Parabéns, FFCLRP!

Zélia Maria Mendes Biasoli Alves 
